\title{
Living on the rocks: substrate mineralogy and the structure of subtidal rocky substrate communities in the Mediterranean Sea
}

\author{
Paolo Guidetti ${ }^{1}$, Carlo Nike Bianchi ${ }^{2}$, Mariachiara Chiantore ${ }^{2}$, \\ Stefano Schiaparelli ${ }^{2}$, Carla Morri ${ }^{2}$, Riccardo Cattaneo-Vietti ${ }^{2, *}$ \\ ${ }^{1}$ Department of Biological and Environmental Sciences and Technology, University of Lecce, Via Prov le Monteroni, \\ 73100 Lecce, Italy \\ ${ }^{2}$ Department for the Study of Territory and its Resources, University of Genoa, Corso Europa 26, 16132 Genoa, Italy
}

\begin{abstract}
Distribution patterns of epibenthic assemblages, sea urchins and fishes were assessed in NE Sardinia (Mediterranean Sea) in shallow (4 to $7 \mathrm{~m}$ depth) rocky habitats with 2 rock-type substrates, i.e. limestone and granite, to examine possible differences related to the mineralogical composition of rocks. Sessile organisms and sea urchins were sampled in situ within quadrats. Fishes were assessed by visual census transects. Sessile epibenthic assemblages significantly differed between granite and limestone substrates, and the number of epibenthic sessile taxa was greater on limestone. Average cover of the algae mat (unidentified mixture of filamentous and mucilaginous algae) was significantly greater on granite than limestone, while no significant differences were detected in total cover or in the average cover of the remaining most common epibenthic taxa. Densities of sea urchins (i.e. Paracentrotus lividus and Arbacia lixula) did not differ between the 2 rock types. Fish assemblages were significantly different between granite and limestone rock substrates. Labrids of the genus Symphodus and Serranus scriba were more abundant on granite, whereas Serranus cabrilla, Parablennius rouxi, Gobius bucchichi and Thalassoma pavo showed greater densities on limestone. Sarpa salpa (the most important herbivorous fish in the Mediterranean sublittoral) did not show any significant difference between granite and limestone substrates. These results suggest that rock type may have the potential to influence marine assemblages, probably through direct effects on epibenthic organisms (e.g. the presence of quartz and substrate texture, both related to the mineralogical features of rocks), and indirect effects on fishes (e.g. the influence of the structure of the epibenthic cover). These results suggest a possible role of the mineralogical composition of rocks in 'bottom-up' processes influencing marine assemblages in shallow sublittoral rocky habitats in the Mediterranean, where direct effects on sessile organisms (e.g. macroalgae) may cascade up through the entire community and affect higher trophic levels (e.g. carnivorous fishes). However, extensive experimental work is needed before drawing any conclusion about the specific processes determining the patterns we observed.
\end{abstract}

KEY WORDS: Shallow rock substrates $\cdot$ Biomineralogy $\cdot$ Epibenthos $\cdot$ Sea urchins $\cdot$ Fishes $\cdot$ Community structure $\cdot$ Western Mediterranean

\section{INTRODUCTION}

Many authors have provided evidence that assemblages of marine benthic organisms and fishes associated with subtidal rocky substrates are characterised by an intrinsic variability in their patterns of distribu- tion due to changes in abiotic factors (e.g. wave action, water temperature, salinity, habitat complexity), biological processes (e.g. recruitment, predation and competition), and their interplay (Paine \& Levin 1981, Dayton 1984, Sousa 1984, Menge \& Southerland 1987, Barry \& Dayton 1991, Levin 1993, Horne \& Schneider 
1995, Bianchi 1997, Smith \& Witman 1999, BenedettiCecchi et al. 2000, Wellenreuther \& Connell 2002). The importance of substrate complexity, surface texture and physico-chemical properties of rocks upon the composition and structure of epibenthic and/or fish communities has long been recognised (Den Hartog 1972, Luckhurst \& Luckhurst 1978, Caffey 1982, Roberts \& Ormond 1987, Raimondi 1988, Bourget et al. 1994, Connell \& Glasby 1999, Angel \& Ojeda 2001). Little attention, however, has been paid to the biological effects of mineralogical features of substrates (Cerrano et al. 1998, Sousa 2001). Most of the available information about the effects of mineralogical features of rocks on sessile benthos chiefly concerns endolithic organisms (e.g. clionid sponges and bivalves), whose boring activity is known to be widespread in substrates rich in carbonates, and to be hampered, for instance, by the presence of quartz (Bavestrello et al. 2000 and references therein). Recently, mineralogical features of substrates have been observed to influence infaunal colonisation in marine soft bottoms (Cerrano et al. 1998), hydroid settlement and epibenthic community structure in marine sublittoral rocky substrates (Bavestrello et al. 2000), bacterial activity in marine sediments (Manini \& Luna 2003), distribution patterns of vermetid molluscs (Schiaparelli et al. 2003), settlement of barnacle larvae (Faimali et al. 2004), case-building in freshwater Trichoptera (Gaino et al. 2002), and larval development in freshwater fishes (Maradonna et al. 2003). All these studies suggest that the mineralogical composition of rocky and soft substrates could have a greater influence than previously thought. Cerrano et al. (1998) thus introduced the term 'biomineralogy' to indicate the wide array of possible interrelationships between biological systems at different hierarchies (cell, organism, species, community) and the mineralogical composition of substrates.

Many studies have focused on top-down processes and their potential in controlling community structure on subtidal rocky substrates in temperate regions (Witman \& Dayton 2001 and references therein). Although no experimental evidence has yet been provided to describe the specific mechanisms through which rock type may affect marine organisms (e.g. composition, texture, microtopography, epibiotic cover), there is an increasing body of evidence suggesting that mineralogical features of rocks could affect marine assemblages both directly (e.g. sessile epibenthos: Bavestrello et al. 2000, Cattaneo-Vietti et al. 2002) and indirectly (e.g. fish: Guidetti \& CattaneoVietti 2002). This could imply that rock type effects on epibenthic assemblages have the potential to cascade upwards through the entire community, influencing (for instance) sea urchins and fishes (including the main predators of sea urchins in the Mediterranean
Sea: Sala et al. 1998a). Mineralogical features of rocks could thus affect the structure of hard-substrate communities from primary producers (i.e. macroalgae) to consumers (sea urchins and fishes), and therefore interact with top-down processes; yet no studies have simultaneously taken into account sessile epibenthos, sea urchins and fishes in temperate rocky substrates, and evaluated possible differences related to the mineralogical composition of rocks.

The purpose of this study, therefore, is to assess whether the mineralogical composition of rocks (i.e. granite versus limestone) may have the potential to influence distribution patterns of epibenthic sessile assemblages, sea urchins and fishes associated with shallow sublittoral rocky substrates in the western Mediterranean.

\section{MATERIALS AND METHODS}

Study area and sampling design. Visual assessments of sessile epibenthic assemblages, sea urchins and fishes were performed in June 2001 on rocky substrates at about 4 to $7 \mathrm{~m}$ depth in NE Sardinia (Mediterranean Sea, Italy; Fig. 1). The highly indented stretch of coast investigated in the present study encompasses tens of kilometres, and is mostly comprised of granite rocks, with the exceptions of Capo Figari Promontory and Tavolara Island, both of which consist of gigantic limestone-dolomite slabs (Navone et al. 1992; Fig. 1). We selected 4 locations about 2 to $5 \mathrm{~km}$ apart, 2 on granite (Molara and Capo Ceraso) and 2 on limestone (Capo Figari and Tavolara) (Fig. 1). At each location, 3 sites a few hundreds of metres apart, were randomly chosen.

Sampling procedures. Environmental features such as wave exposure, slope, rugosity and presence of boulders are known to influence the distribution patterns of epibenthos, sea urchins and fishes (BenedettiCecchi \& Cinelli 1995, Glasby 2000, García-Charton \& Perez-Ruzafa 2001). The random selection of sites allowed us to sample exposed and sheltered sites at each granite and limestone location. To avoid any possible confounding (see Underwood 1997) between putative effects of mineralogical rock types and the above-mentioned environmental features, slope, rugosity and presence of boulders were also quantified. Slope was measured by a hand-held clinometer with a precision of $5^{\circ}$. We made 6 random readings at each of the 3 sites within each of the 4 locations. Rugosity was estimated as the ratio (L/l) between real length (L) measured with a chain contoured over the bottom, and the linear distance (l) between the chain's endpoints (Garcia-Charton \& Pérez-Ruzafa 2001 and references therein); 20 replicate measurements were made at 


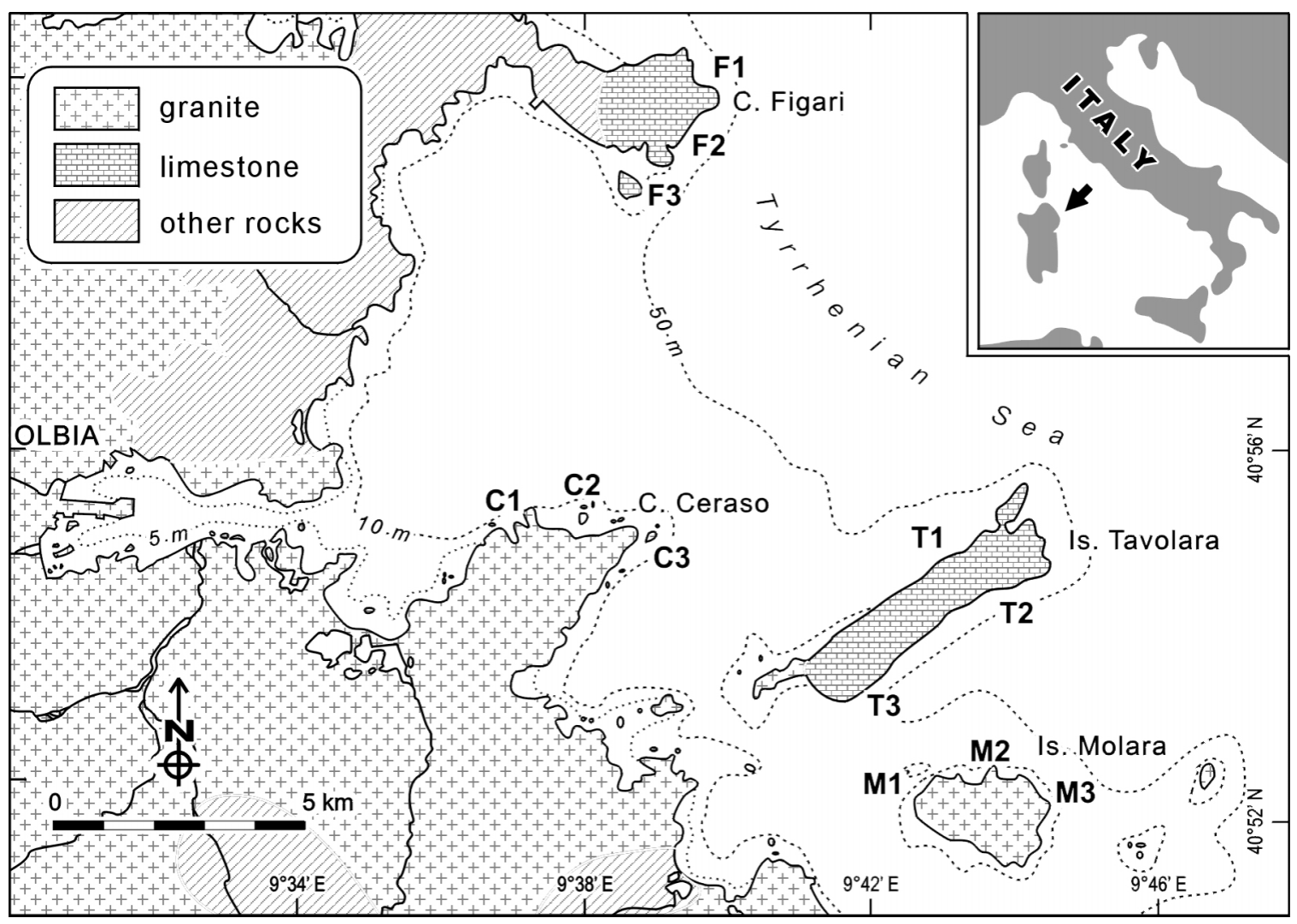

Fig. 1. Sampling locations (F: Capo Figari; C: Capo Ceraso; T: Tavolara; M: Molara), sites within each location (1, 2, 3), and dominant rock types in the study area

each site. Rocky boulders (sensu Garcia-Charton \& Pérez-Ruzafa 1998, 2001), were counted and classified according to major length, ML (i.e. the longest rock face) as small (ML $\leq 1 \mathrm{~m})$, medium $(1 \mathrm{~m}<\mathrm{ML} \leq 2 \mathrm{~m})$ and large (ML $>2 \mathrm{~m})$.

Subtidal sessile epibenthos was visually recorded within 6 randomly placed quadrats at each site. Quadrats were $0.25 \mathrm{~m}^{2}$ in surface area, and were divided into 25 equal squares $10 \times 10 \mathrm{~cm}$. The percent substrate cover of conspicuous organisms was quantified by scoring each individual taxon in each square as follows: 0 = absence, $1=\sim 25 \%$ cover, $2=\sim 50 \%$ cover, $3=\sim 75 \%$ cover and $4=$ virtually the whole square. Organisms filling less than $25 \%$ of a square were given an arbitrary value of 0.5 . Scores for all 25 small squares were then summed, and the final values expressed as percentages (Fraschetti et al. 2001 and references therein). Conspicuous organisms were recorded in the field, and identified to species whenever possible, with collection of voucher specimens for later identification confined to a few doubtful cases.

Sea urchin abundance was assessed by counting all individuals larger than $1 \mathrm{~cm}$ in diameter (test without spines; Sala \& Zabala 1996), thus keeping species dis- tinct. Counts were made within strip transects roped off into 10 adjacent $1 \mathrm{~m}^{2}$ quadrats. A whole transect $(10 \times 1 \mathrm{~m})$ comprised a basic sampling unit, and 3 replicate transects were randomly placed at each of the 3 sites within each of the 4 locations.

Fish assemblages were assessed along $25 \mathrm{~m}$ long $\times$ $5 \mathrm{~m}$ wide transects (Harmelin-Vivien et al. 1985). We randomly placed 5 replicate transects (spaced tens to hundreds of metres from each other) at each of the 3 sites within each of the 4 locations. The transect technique was selected as the most appropriate method for accurately recording smaller specimens and fastswimming species. Density of fishes was estimated by counting single specimens to a maximum of 10 individuals of each species encountered, while abundance classes (11 to 30,31 to 50, 51 to 100, 101 to 200, 201 to 500 individuals) were used for more abundant species.

Data treatment. Epibenthic and fish assemblage structures were analysed by multivariate techniques using the PRIMER software package (Plymouth Marine Laboratory, UK; Clarke \& Warwick 1994). Data on epibenthic cover and fish density were appropriately transformed (square-root and log-transformation, for epibenthos and fishes, respectively) to reduce the in- 
fluence of abundant taxa in the analyses. The BrayCurtis similarity matrix was used to generate 2D nonmetric multidimensional scaling (nMDS) (Clarke 1993). A 2-way nested analysis of similarity (ANOSIM; Clarke 1993) was first used to examine differences among sites and among locations in order to detect at which spatial scale epibenthos and fish assemblages were most variable. As differences at the spatial scale of sites within locations were significant, but lower than those among locations for both epibenthos and fish assemblages (see 'Results'), data from each site within each location were used as replicates in order to perform an ANOSIM test for differences in relation to mineralogical rock types and over the scale of locations.

The similarity percentages procedure (SIMPER: Clarke 1993) was employed to identify the major epibenthic and fish taxa contributing to the differences between the 2 mineralogical rock types.

Analysis of variance (ANOVA) was used to assess putative differences in the variables under investigation (listed below) between rock types (granite versus limestone: Gr vs Lim), among locations within rock type, and among sites within location. Rock type (Gr vs Lim) was considered as a fixed factor, Location (L) was nested within Rock type, and Site (S) was randomly nested within Location. ANOVA was used to analyse (1) environmental features: slope, rugosity, number of boulders of different size; (2) sessile epibenthos: number of taxa, total cover, and cover of the most representative taxa, arbitrarily selected as those contributing more than $3 \%$ to the dissimilarity between the 2 mineralogical rock types (based on the SIMPER procedure); (3) sea urchins: density of each individual species; (4) fishes: number of taxa, total density, and density of the most representative fish taxa (following the same criteria as those used for selecting representative taxa of the epibenthos).

Prior to analyses, the homogeneity of variances was tested by Cochran's C-test and, whenever necessary, data were appropriately transformed. Whenever transformations did not produce homogeneous variances, ANOVA was used, however, after setting $\alpha=0.01$ to compensate for the increased likelihood of Type I error. SNK tests were run when analyses detected significant differences (Underwood 1997).

\section{RESULTS}

\section{Environmental features}

ANOVAs performed on environmental features showed that slope, rugosity and number of boulders of the 3 size categories (small, medium and large; see 'Materials and methods') did not vary significantly between granite and limestone substrates, or at the spatial scale of locations. Significant differences were only detected in slope and in the number of small and medium boulders at the spatial scale of sites within location (Table 1). This implies that the abovementioned environmental features potentially generate variability in the biological variables measured at the spatial scale of sites. The comparison between rock types was not affected by any confounding effect.

\section{Epibenthic sessile assemblages}

We identified 47 taxa (21 of which were algae) at the 4 locations examined. 'Algal mat' was used to define an unidentified mixture of filamentous and mucilaginous algae, possibly a seasonal feature. Sessile animals were mainly represented by sponges (11 taxa) and bryozoans (6), followed by molluscs (3), tubicolous polychaetes (3), and by cnidarians (1), barnacles (1) and ascidians (1).

The nMDs plot of the epibenthic assemblages shows a clear-cut separation between the centroids of each series of replicates from each granite and limestone site (Fig. 2A). In addition, epibenthic assemblages from granite were tightly grouped, whereas those from

Table 1. Summaries of ANOVAs on environmental features (substrate slope, rugosity and number of boulders of different size) testing for differences between rock types, Granite (Gr) versus Limestone (Lim), and over spatial scales of locations (L) and sites (S). ns: not significant; ${ }^{*}: \mathrm{p}<0.05$

\begin{tabular}{|lccc|}
\hline \multirow{2}{*}{ Variable } & \multicolumn{3}{c|}{ Source of variation } \\
\cline { 2 - 4 } & Rock (Gr vs Lim) & L & S \\
\hline Slope & $\mathrm{ns}$ & $\mathrm{ns}$ & $*$ \\
Rugosity & $\mathrm{ns}$ & $\mathrm{ns}$ & $\mathrm{ns}$ \\
Small boulders & $\mathrm{ns}$ & $\mathrm{ns}$ & ${ }^{*}$ \\
Medium boulders & $\mathrm{ns}$ & $\mathrm{ns}$ & ${ }^{*}$ \\
Large boulders & $\mathrm{ns}$ & $\mathrm{ns}$ & $\mathrm{ns}$ \\
& & & \\
\hline
\end{tabular}

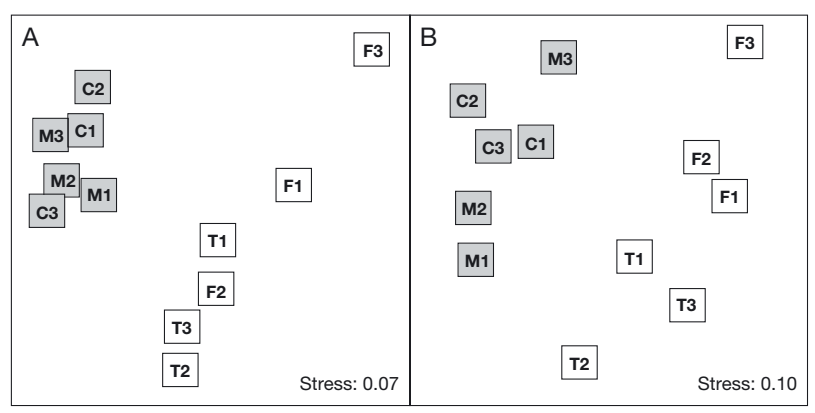

Fig. 2. (A) Epibenthic and (B) fish assemblages. Two-dimensional nMDS ordinations of centroids of each series of replicates in each granite (grey quadrats) and limestone (white quadrats) sampling site (site codes as in Fig. 1) 
limestone were dispersed, suggesting that epibenthic assemblages on granite are more homogenous than those on limestone.

A 2-way nested ANOSIM showed that epibenthic sessile assemblages varied significantly among locations and among sites within locations. Dissimilarity among locations was greater than that among sites (Table 2). Pairwise comparisons among the 4 locations revealed that the smallest dissimilarities occurred between locations characterised by the same mineralogical rock type. However, none of the values for the pairwise comparisons of the 4 locations was significant, probably due to the low number of possible permutations $(\mathrm{n}=10)$ in the analyses.

A 2-way nested ANOSIM testing for differences between the 2 mineralogical rock types and among locations showed that neither factor was significant (rock type: $\mathrm{R}=1, \mathrm{p}=0.33$; location: $\mathrm{R}=0.37, \mathrm{p}=0.07$ ). It is worth noting, nevertheless, that the dissimilarity between rock types was far greater than that among locations. The lack of statistical significance for such a clear-cut difference between rock types is due to the fact that ANOSIM testing for dissimilarity between rock types had only 3 possible permutations.

SIMPER showed that 20 taxa individually contributed to more than $3 \%$ of the dissimilarity between the 2 rock types, with 8 taxa showing larger cover values on granite and 12 with larger values on limestone (Table 3).

ANOVA showed that the number of taxa (Fig. 3A) was slightly, but significantly, greater on limestone than on granite. Significant variability was also observed at the spatial scale of sites, but not at the scale of locations within each rock type (Table 4). Total cover (Fig. 3B) was not significantly different between the 2 rock types (Table 4), nor did it vary at the scale of locations, while significant variability was detected at the scale of sites. In addition, ANOVAs performed on individual taxa showed that only algal mat cover was significantly different between the 2 rock types, being

Table 2. Results of 2-way nested ANOSIM testing for differences in sessile benthic assemblages among locations and sites (location codes as in Fig. 1)

\begin{tabular}{|lcc|}
\hline Global R, p & R value & $\mathrm{p}$ \\
\hline Among locations & 0.620 & 0.001 \\
Among sites & 0.429 & 0.001 \\
& & \\
Pairwise tests & & \\
M vs C & 0.556 & 0.20 \\
M vs F & 0.852 & 0.10 \\
M vs T & 0.926 & 0.10 \\
C vs F & 0.852 & 0.10 \\
C vs T & 0.963 & 0.10 \\
F vs T & 0.185 & 0.40 \\
\hline
\end{tabular}

greater on granite than on limestone. The remaining epibenthic taxa mainly varied at the scale of sites, and did not display any significant difference between granite and limestone. Only Lithophyllum incrustans showed a significant variability at the spatial scale of locations (Table 4).

Table 3. Results of SIMPER (similarity percentages procedure) analysis showing sessile benthic taxa contributing most (in order of decreasing percentage) to dissimilarity between granite and limestone sites and average cover (\%) on the 2 mineralogical rock types. See 'Materials and methods' for details

\begin{tabular}{|lrrr|}
\hline \multirow{2}{*}{ Taxon } & $\begin{array}{c}\text { Dissimilarity } \\
\text { contribution }\end{array}$ & $\begin{array}{c}\text { - Average cover } \\
\text { Granite }\end{array}$ \\
& & & \\
& Limestone \\
Lithophyllum incrustans & 7.90 & 4.6 & 13.5 \\
Dasycladus vermicularis & 5.44 & 2.3 & 0.6 \\
Amphiroa rigida & 5.29 & 0.3 & 1.6 \\
Algae mat & 5.07 & 29.8 & 21.9 \\
Padina pavonia & 4.70 & 6.9 & 5.6 \\
Schizoporella longirostris & 4.45 & 1.3 & 0.1 \\
Dictyota dichotoma & 4.14 & 6.7 & 9.0 \\
Stypocaulon scoparium & 3.92 & 1.1 & 0.8 \\
Acetabularia acetabulum & 3.89 & 8.0 & 5.6 \\
Halimeda tuna & 3.74 & 0.1 & 1.1 \\
Cliona sp. & 3.74 & 0.0 & 0.8 \\
Crambe crambe & 3.59 & 6.9 & 4.6 \\
Reptadeonella violacea & 3.35 & 0.9 & 1.5 \\
Calpensia nobilis & 3.30 & 0.0 & 0.4 \\
Ircinia fasciculata & 3.27 & 0.1 & 0.7 \\
Flabellia petiolata & 3.22 & 0.5 & 0.9 \\
Jania rubens & 3.20 & 0.6 & 0.8 \\
Vermetus triquetrus & 3.16 & 0.9 & 0.2 \\
Peyssonnellia spp. & 3.15 & 0.6 & 1.2 \\
Sarcotragus spinosolus & 3.09 & 0.0 & 0.5 \\
\hline
\end{tabular}
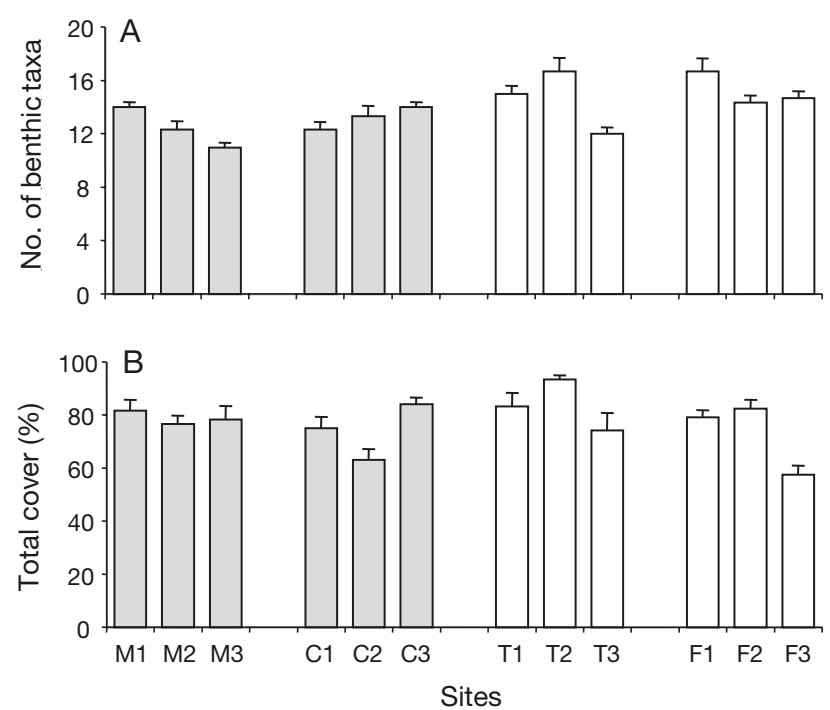

Fig. 3. (A) Epibenthic taxa mean $( \pm \mathrm{SE})$ number and (B) total cover in each granite (grey bars) and limestone (white bars) sampling site (site codes as in Fig. 1) 
Table 4. Summaries of ANOVAs on number of sessile benthic taxa, total cover, and cover of each relevant sessile benthic taxon, testing for effects of rock type, Granite (Gr) versus Limestone (Lim), and over spatial scales of locations (L) and sites (S). ns: not significant; ${ }^{*} \mathrm{p}<0.05 ;{ }^{* *} \mathrm{p}<0.01$

\begin{tabular}{|c|c|c|c|}
\hline \multirow{2}{*}{ Variable } & \multicolumn{3}{|c|}{ - Source of variation } \\
\hline & Rock (Gr vs Lim) & $\mathrm{L}$ & $\mathrm{S}$ \\
\hline No. of sessile benthic taxa & ${ }^{*}(\mathrm{Gr}<\mathrm{Lim})$ & $\mathrm{ns}$ & ** \\
\hline Total cover & $\mathrm{ns}$ & $\mathrm{ns}$ & ** \\
\hline Lithophyllum incrustans & ns & $*$ & ** \\
\hline Dasycladus vermicularis & ns & ns & ** \\
\hline Amphiroa rigida & $\mathrm{ns}$ & $\mathrm{ns}$ & ** \\
\hline Algae mat & ${ }^{*}(\mathrm{Gr}>\mathrm{Lim})$ & $\mathrm{ns}$ & ** \\
\hline Padina pavonica & $\mathrm{ns}$ & $\mathrm{ns}$ & ** \\
\hline Schizoporella longirostris & ns & $\mathrm{ns}$ & ns \\
\hline Dictyota dichotoma & $\mathrm{ns}$ & $\mathrm{ns}$ & ns \\
\hline Stypocaulon scoparium & $\mathrm{ns}$ & ns & $* *$ \\
\hline Acetabularia acetabulum & $\mathrm{ns}$ & ns & ** \\
\hline Halimeda tuna & $\mathrm{ns}$ & ns & $*$ \\
\hline Cliona sp. & ns & ns & ** \\
\hline Crambe crambe & ns & ns & ** \\
\hline Reptadeonella violacea & ns & ns & $* *$ \\
\hline Calpensia nobilis & $\mathrm{ns}$ & $\mathrm{ns}$ & ns \\
\hline Ircinia fasciculata & $\mathrm{ns}$ & $\mathrm{ns}$ & $* *$ \\
\hline Flabellia petiolata & ns & $\mathrm{ns}$ & ** \\
\hline Jania rubens & ns & ns & ** \\
\hline Vermetus triquetrus & ns & ns & ** \\
\hline Peyssonnellia spp. & ns & ns & ** \\
\hline Sarcotragus spinusolus & ns & $\mathrm{ns}$ & ${ }^{*}$ \\
\hline
\end{tabular}

\section{Sea urchins}

We found 2 species of sea urchins, Paracentrotus lividus and Arbacia lixula, at the 4 locations investigated.

ANOVAs on densities of these 2 species (Fig. 4) did not reveal any significant difference related to mineralogical rock type. Also, no difference was detected between locations within each rock type, whereas significant variability was observed at the scale of sites within locations (Table 5).

\section{Fish assemblages}

We recorded 38 fish taxa at the 4 sampling locations. The more speciose families were labrids (12 species, most belonging to the genus Symphodus) and sparids (7 species).

The nMDS plot of fish assemblages (Fig. 2B) shows that the centroids of each series of replicates from the granite sites were separated from those from limestone sites, as observed for the epibenthos. Fish assemblages from granite sites appeared again to be more homogeneous than those from limestone sites, but the differences in dispersion among granite and limestone sites
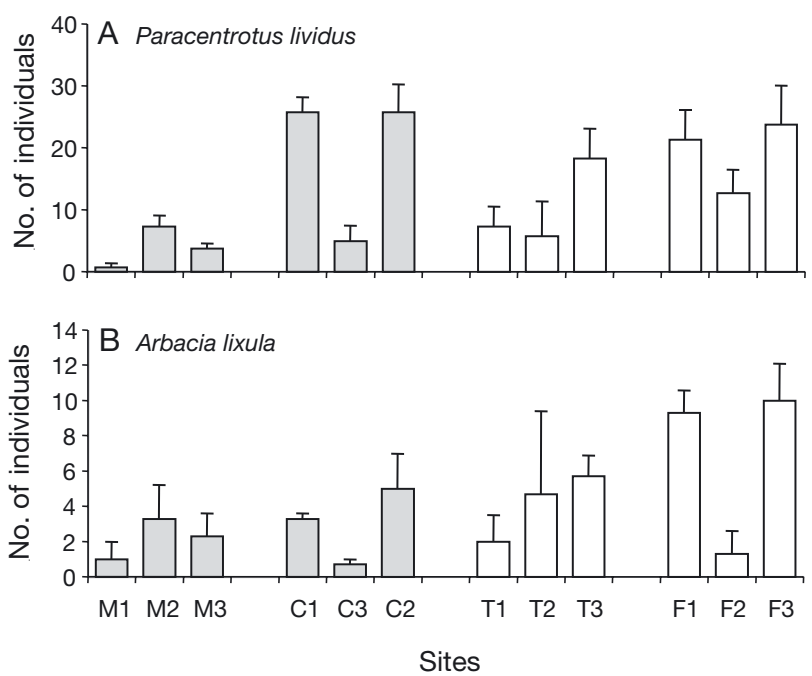

Fig. 4. (A) Paracentrotus lividus and (B) Arbacia lixula: mean $\left( \pm\right.$ SE) density (no. of individuals $10 \mathrm{~m}^{-2}$ ) of sea urchins at each granite (grey bars) and limestone (white bars) sampling site (site codes as in Fig. 1)

was less pronounced than those for the epibenthic assemblages.

A 2-way nested ANOSIM showed that differences in fish assemblage structures were greater among locations than among sites within locations (Table 6). Pairwise comparisons showed that the values of dissimilarity between locations with the same mineralogical rock type were lower than those observed comparing granite versus limestone locations (Table 6). The fact that none of the pairwise tests was significant is again attributable to the low number of permutations possible $(\mathrm{n}=10)$. A 2-way nested ANOSIM was then performed to test for differences in fish assemblages between the 2 mineralogical rock types and among locations. The global $\mathrm{R}$ value of dissimilarity between rock types was greater than that among locations $(\mathrm{R}=1.0, \mathrm{p}=0.33$ vs $\mathrm{R}=0.54, \mathrm{p}=0.01)$, but only the latter was significant. Similar to epibenthic assemblages, the non-significant result for the factor 'rock type' is due to the fact that this test had only 3 possible permutations.

Table 5. Summaries of ANOVAs on sea urchin density testing for effects of rock type, Granite (Gr) versus Limestone (Lim), and over spatial scales of locations (L) and sites (S). ns: not significant; ${ }^{*} \mathrm{p}<0.05{ }_{i}^{* *} \mathrm{p}<0.01$

\begin{tabular}{|lccc|}
\hline \multirow{2}{*}{ Variable } & \multicolumn{3}{c|}{ Source } \\
\cline { 2 - 4 } & Rock (Gr vs Lim) & L & S \\
\hline Paracentrotus lividus & $\mathrm{ns}$ & $\mathrm{ns}$ & ${ }^{* *}$ \\
Arbacia lixula & $\mathrm{ns}$ & $\mathrm{ns}$ & ${ }^{*}$ \\
\hline
\end{tabular}


Table 6. Results of 2-way nested ANOSIM testing for differences in fish assemblage structures among locations and sites (location codes as in Fig. 1)

\begin{tabular}{|lcc|}
\hline Global R, p & R value & $\mathrm{p}$ \\
\hline Among locations & 0.515 & 0.004 \\
Among sites & 0.182 & 0.001 \\
& & \\
Pairwise tests & & \\
M vs C & 0.074 & 0.40 \\
M vs F & 0.778 & 0.10 \\
M vs T & 0.370 & 0.20 \\
C vs F & 1.000 & 0.10 \\
C vs T & 0.741 & 0.10 \\
F vs T & 0.333 & 0.10 \\
\hline
\end{tabular}

SIMPER revealed that 16 fish taxa individually contributed more than $3 \%$ to the dissimilarity between the 2 mineralogical rock types: 10 taxa were more abundant on limestone and 6 were more abundant on granite (Table 7). All labrids belonging to the genus Symphodus were more abundant on granite than on limestone, and cumulatively contributed more than $22 \%$ to the dissimilarity between fish assemblages on the 2 rock types. Conversely, Oblada melanura, Apogon imberbis and Chromis chromis were chiefly associated with limestone, and accounted for more than $20 \%$ of the dissimilarity between limestone and granite (Table 7).

The number of fish taxa (Fig. 5A) did not differ significantly between the 2 mineralogical rock types, or between the 2 spatial scales examined (i.e. among locations within rock type, or among sites within locations). Total fish density (Fig. 5B) did not vary between mineralogical rock types or among sites, but showed a significant variability at the scale of locations (Table 8).

Symphodus melanocercus, S. roissali, S. mediterraneus, and Serranus scriba were significantly more abundant on granite than on limestone. Parablennius rouxi, Serranus cabrilla, Thalassoma pavo and Gobius bucchichi, conversely, showed a significantly greater density on limestone than on granite. The remaining fish taxa did not display any significant difference related to the mineralogical rock type (Table 8 ).

\section{DISCUSSION}

The present study has provided evidence of differences in the structure of shallow Mediterranean epibenthic and fish assemblages associated with sublittoral hard substrates constituted by different mineralogical rock types, granite and limestone.
Table 7. Results of SIMPER analysis showing fish taxa contributing most (in order of decreasing percentage) to dissimilarity between granite and limestone sites and average abundance on the 2 mineralogical rock types. See 'Materials and methods' for details

\begin{tabular}{|lcrc|}
\hline \multirow{2}{*}{ Taxon } & $\begin{array}{c}\text { Dissimilarity } \\
\text { contribution }\end{array}$ & \multicolumn{2}{c|}{$\begin{array}{c}\text { Average cover } \\
\text { Granite }\end{array}$} \\
& Limestone \\
\hline Oblada melanura & 7.07 & 1.8 & 3.7 \\
Apogon imberbis & 6.73 & 3.8 & 5.0 \\
Symphodus melanocercus & 6.67 & 1.7 & 0.2 \\
Symphodus ocellatus & 6.49 & 2.1 & 0.9 \\
Chromis chromis & 6.38 & 184.4 & 347.2 \\
Parablennius rouxi & 5.87 & 0.1 & 1.2 \\
Serranus cabrilla & 5.26 & 1.1 & 3.1 \\
Serranus scriba & 4.88 & 3.4 & 1.3 \\
Diplodus sargus & 3.82 & 0.8 & 1.9 \\
Diplodus vulgaris & 3.79 & 11.7 & 13.5 \\
Thalassoma pavo & 3.78 & 1.4 & 2.7 \\
Sarpa salpa & 3.53 & 11.8 & 14.7 \\
Symphodus rostratus & 3.26 & 0.7 & 0.3 \\
Symphodus roissali & 3.18 & 0.5 & 0.1 \\
Gobius bucchichi & 3.08 & 0.1 & 0.4 \\
Symphodus mediterraneus & 3.02 & 1.4 & 0.8 \\
\hline
\end{tabular}
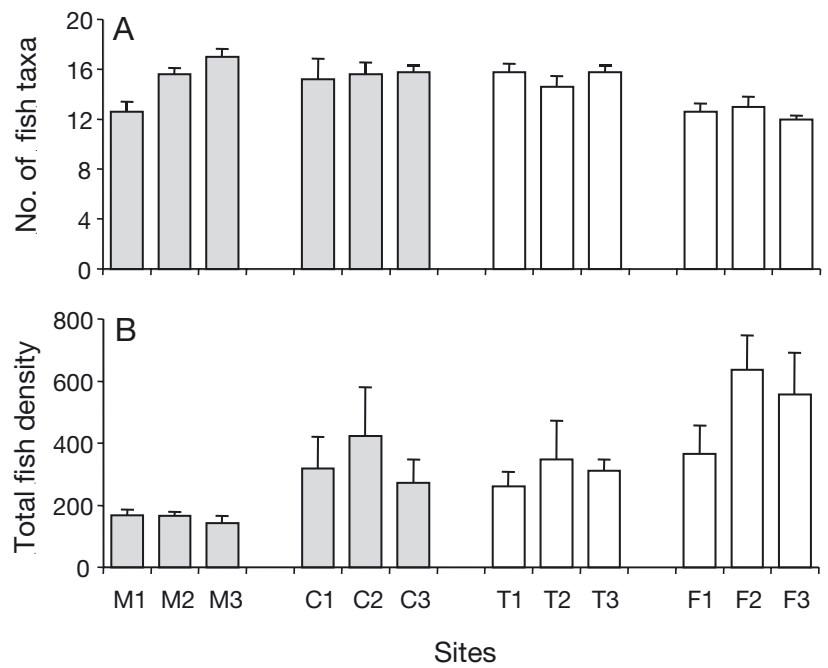

Fig. 5. (A) Mean ( \pm SE) number of fish taxa and (B) total fish density (no. of individuals $125 \mathrm{~m}^{-2}$ ) at each granite (grey bars) and limestone (white bars) sampling site (site codes as in Fig. 1)

Exposure to wave action was equal at both granite and limestone sampling sites, and macro-topographic features such as slope, rugosity and presence of boulders of different size did not differ between the granite and limestone substrates. We can therefore exclude any significant confounding effect (sensu Underwood 1997) due to such environmental features.

Multivariate analyses showed similar patterns for both epibenthic and fish assemblages, providing evidence of clear-cut differences related to the mineralog- 
Table 8. Summaries of ANOVAs on fish taxa, total fish density and density of each relevant fish taxon testing for effects of rock types, Granite (Gr) versus Limestone (Lim), and over spatial scales of locations (L) and sites (S). ns: not significant; ${ }^{*} \mathrm{p}<0.05 ;{ }^{* *} \mathrm{p}<0.01$

\begin{tabular}{|c|c|c|c|}
\hline \multirow{2}{*}{ Variable } & \multicolumn{3}{|c|}{ - Source of variation } \\
\hline & Rock (Gr vs Lim) & $\mathrm{L}$ & $\mathrm{S}$ \\
\hline No. of fish taxa & ns & ns & ns \\
\hline Total fish density & ns & ${ }^{*}$ & ns \\
\hline Oblada melanura & ns & ns & ns \\
\hline Apogon imberbis & ns & ns & ** \\
\hline Symphodus melanocercus & ${ }^{*}(\mathrm{Gr}>\mathrm{Lim})$ & ns & ** \\
\hline Symphodus ocellatus & ns & ns & ** \\
\hline Chromis chromis & ns & ${ }^{* *}$ & $\mathrm{~ns}$ \\
\hline Parablennius rouxi & ${ }^{*}(\mathrm{Gr}<\mathrm{Lim})$ & ns & $\mathrm{ns}$ \\
\hline Serranus cabrilla & ${ }^{* *}(\mathrm{Gr}<\mathrm{Lim})$ & ns & $\mathrm{ns}$ \\
\hline Serranus scriba & ${ }^{*}(\mathrm{Gr}>\mathrm{Lim})$ & ns & $\mathrm{ns}$ \\
\hline Diplodus sargus & ns & ns & * \\
\hline Diplodus vulgaris & ns & ns & ns \\
\hline Thalassoma pavo & ${ }^{*}(\mathrm{Gr}<\mathrm{Lim})$ & ns & $\mathrm{ns}$ \\
\hline Sarpa salpa & ns & ns & $\mathrm{ns}$ \\
\hline Symphodus rostratus & ns & ns & * \\
\hline Symphodus roissali & ${ }^{* *}(\mathrm{Gr}>\mathrm{Lim})$ & ns & $\mathrm{ns}$ \\
\hline Gobius bucchichi & ${ }^{* *}(\mathrm{Gr}<\mathrm{Lim})$ & ns & ns \\
\hline Symphodus mediterraneus & $s \quad{ }^{*}(\mathrm{Gr}>\operatorname{Lim})$ & ns & $\mathrm{ns}$ \\
\hline
\end{tabular}

ical type of rock. A greater similarity was detected within assemblages associated with granite, particularly for the sessile epibenthos. Nevertheless, we have no indication as to which mechanisms underlie the greater heterogeneity observed on limestone, an issue that deserves further investigation.

As far as the sessile epibenthos is concerned, univariate tests detected statistically significant difference only in the cover of the algal mat. The cover of most epibenthic taxa varied greatly at the scale of sites, and this probably obscured any slight difference in cover between the 2 rock types. However, all these small differences (together with the significant difference in the cover of the algae mat) cumulated in the multivariate analyses, and are likely to have caused the clear-cut difference between granite and limestone in the overall epibenthic assemblages. Also, specific univariate tests for the main effect of rock type had a low number of degrees of freedom, which negatively influenced the power of the tests, and thus lessened the possibility of detecting a significant response in some variables.

Many of the algae species that (on the whole) had slightly (but not significantly) greater cover on granite were fully photophilic (e.g. Padina pavonica, Stypocaulon scoparium and Acetabularia acetabulum), while those on limestone were more sciaphilic (e.g. Halimeda tuna, Flabellia petiolata and Peyssonnelia spp.; see Boudouresque 1984). Since there was no difference in depth, slope and rugosity between the 2 rock types, the hypothesis of differences in light avail- ability does not seem tenable. Substrate microrelief, however, may create different conditions of illumination at the microscale (e.g. $\mathrm{mm}$ to $\mathrm{cm}$ ), potentially influencing the structure of sessile epibenthic assemblages, especially during the initial phases of development (Bianchi 1979). Microrelief is a consequence of surface texture and hardness of rocky substrates which, in turn, depend on their mineralogical composition. The different intrinsic hardness of the 2 rock types (higher in granite than limestone), together with possible differences in sedimentation rates, could further contribute to the observed differences in epibenthic assemblages.

Our data revealed different epibenthic assemblages with a lower species richness and a greater algal mat cover on granite than on limestone. Airoldi (2000) observed that, in subtidal rocky habitats, mats of filamentous algae have a competitive advantage over erect and encrusting algae under conditions of stress. The epibenthic assemblages we found on granite were poorer (in terms of species richness) than those growing on limestone. Although our data do not allow us to relate the patterns observed with any causal process, these outcomes are consistent with the hypothesis that the high content of quartz in granite rocks may exert some physiological stress on the development of marine epibenthic assemblages (Bavestrello et al. 2000). In this connection, quartz has been proved to have clear negative biological effects, mainly on animals that colonise sand, probably due both to the oxidant properties of its crystal surface, which generates silicon-based radicals, and the formation of $\mathrm{OH}$ radicals in the surrounding water (see Cerrano et al. 1998 and references therein).

The sea urchins Paracentrotus lividus and Arbacia lixula are the most common echinoids on shallow subtidal rocky habitats in the Mediterranean, and are considered key species modifying assemblages of macroalgae (Benedetti-Cecchi et al. 1998, Sala et al. 1998a, Bulleri et al. 1999, Boudouresque \& Verlaque 2001). In this respect, records of sublittoral sessile assemblages persisting in an early developmental phase have been frequently interpreted as a consequence of overgrazing by sea urchins (Navone et al. 1992, Balduzzi et al. 1996, Boudouresque \& Verlaque 2001, Guidetti et al. 2003). In our study, sea urchins did not show any significant difference in distribution patterns related to the 2 rock types. They showed a marked heterogeneity at a comparatively small spatial scale, as reported for other areas of the Mediterranean Sea (Guidetti et al. 2003 and references therein). This indicates that the variability in the distribution of sea urchins in the study area is attributable to factors other than mineralogical rock type, and that habitat heterogeneity (e.g. in terms of availability of shelters) could exert a role (Benedetti- 
Cecchi \& Cinelli 1995, Sala \& Zabala 1996). We observed, in fact, that the number and size of boulders varied at the scale of sites within locations, and this is likely to have influenced the distribution patterns of sea urchins at that specific scale. Our results suggest that substrate mineralogy does not affect the distribution patterns of sea urchins. However, as we did not estimate grazing rates experimentally, we cannot exclude a possible role of sea urchin grazing interacting with substrate mineralogy and, therefore, affecting epibenthic assemblages on granite or limestone substrates.

For the fish fauna we observed that whole assemblages and the average density of several fish taxa displayed significant differences between granite and limestone substrates. The fish species chiefly associated with granite were Serranus scriba and labrids belonging to the genus Symphodus, while Serranus cabrilla, Thalassoma pavo and some cryptobenthic fishes were more abundant on limestone. However, the density of Sarpa salpa (the most important herbivorous fish in the Mediterranean sublittoral, and potentially capable of affecting the structure of benthic algal assemblages) did not differ between granite and limestone substrates.

Although this study only provides evidence of differences in their distribution patterns, we can plausibly hypothesise that fishes could be affected by mineralogical rock type in different ways than those potentially affecting epibenthic organisms. Guidetti \& CattaneoVietti (2002) suggested that substrate colour could account for differences in the distribution patterns of some small site-attached fishes associated with granite or limestone rocks. In the present study, the greater abundance of Serranus cabrilla, Parablennius rouxi and Gobius bucchichi (i.e. benthic and light-coloured fishes) on limestone (lighter in colour than granite) could merely be related to the camouflage behaviour of these species (Tortonese 1975, Guidetti \& CattaneoVietti 2002). P. rouxi, in particular, is a small blennid fish that, when disturbed, has often been observed to use empty holes made by the rock-boring date mussel Lithophaga lithophaga as hiding places. Date mussels are exclusively present in carbonatic substrates (these molluscs are able to dissolve these rocks by an acid secretion), so that the specific microhabitat provided by their empty holes is absent from granite substrates. This could explain the far greater abundance of $P$. rouxi on limestone than on granite. The distribution patterns of labrids of the genus Symphodus are known to be influenced by the characteristics of the sessile benthic cover (mainly macroalgae) that provides them with shelter and hosts small mobile invertebrates upon which these fishes feed (Garcia-Rubies \& Macpherson 1995, Ruitton et al. 2000, Letourneur et al. 2003, Guidetti et al. in press). Many epibenthic organisms (chiefly macroalgae and 3-dimensionally structured animals) may, in fact, act as foundation species (Bruno et al. 2003), shaping the submarine seascape and generating habitats for associated mobile invertebrates and fish (Turner et al. 1999, Chemello \& Milazzo 2002). Although there is no univocal opinion about the relationships between sessile epibiota and mobile animals (Chapman 2003), several studies in the Mediterranean Sea have indicated that 'biological conditioning' of the substrate by the epibiota may greatly influence associated mobile invertebrates (Abbiati et al. 1987, 1991, Sardá 1991, Simboura et al. 1995, Chemello \& Milazzo 2002). This hypothesis, in our specific context, is obviously only speculative, but it would seem plausible that the different epibenthic assemblages observed on granite and limestone may provide different structure, and host different mobile invertebrate faunas, thus influencing the distribution patterns of associated mesocarnivorous fishes such as Symphodus spp. (Bell \& Harmelin-Vivien 1983).

Unlike labrids of the genus Symphodus, Thalassoma pavo was more abundant on limestone. Although there is not yet sufficient evidence to fully understand the main factors affecting the distribution of this fish over a local scale (but see Guidetti et al. 2002), there is growing evidence that this labrid, as other similar fish species, could be affected by the availability and type of epibenthic cover (Guidetti et al. in press).

Although ANOVAs detected no significant differences in the average densities of Oblada melanura, Apogon imberbis and Chromis chromis, these 3 species (which were slightly more abundant at the limestone sampling sites) contributed significantly to the differences between the fish assemblages on granite and limestone (see results of SIMPER analyses in Table 7). Considering that such species require temporary (O. melanura and C. chromis) or permanent (A. imberbis) cavitary shelters (Tortonese 1975, Ruitton et al. 2000, Bussotti et al. 2003), these results could indicate that the method we used for evaluating substrate rugosity probably failed to assess possible differences in the availability of cavitary habitats, which could differ in the 2 rocky substrates studied; this will require major consideration in future studies.

The patterns of distribution we observed for the 2 rock types can provide indications as to how mineralogy may affect a whole community associated with shallow subtidal rocky substrates, from primary producers to consumers. It is known that marine communities may be regulated by 'top-down' and/or 'bottom-up' processes (Menge 2000, Duffy \& Hay 2001, Duffy 2002). Top-down processes, in the simplest case, control community structure through negative direct effects of predators on herbivores that then cascade down to positively affect primary producers (Hairston et al. 
1960, Paine 1980, Sala et al. 1998a, Pinnegar et al. 2000). Conversely, bottom-up control is chiefly based on the concept that primary production primarily fuels marine ecosystems (White 1978), and that its effects may then cascade up the community, affecting herbivores and their predators (Hunter \& Price 1992). The 'bottom-up control concept' has been widened to encompass not only the effects on ecosystems strictly connected with changes in primary production, but also with any other process influencing basal species and able to reverberate throughout the entire community (Menge 2000). Might thus biomineralogy be part of a bottom-up process? In the present study, we simultaneously sampled epibenthos (which includes benthic primary producers and structural species such as many macroalgae), sea urchins (the most important herbivores in the shallow Mediterranean rocky sublittoral) and fishes (including the herbivorous species Sarpa salpa, mesocarnivorous labrids and serranids, and the most important predators of sea urchins such as the sparids Diplodus sargus and D. vulgaris; see Sala et al. 1998a). The abundance of sea urchins (Paracentrotus lividus and Arbacia lixula), herbivorous fishes ( $S$. salpa), and fish predators of sea urchins (e.g. D. sargus and $D$. vulgaris) did not differ between granite and limestone rocks. However, we did not carry out any experimental assessment of feeding rates of predators and grazers, so that we cannot draw any conclusion about the actual importance of top-down processes in controlling the structure of sublittoral rocky substrate communities (Sala \& Zabala 1996, Sala et al. 1998b). We did obtain some correlative evidence that the mineralogical composition of rocky substrates could exert a role in bottom-up processes influencing subtidal communities, an aspect that has been neglected in previous studies. Thus, biomineralogically triggered bottom-up processes could interact with top-down and other bottomup (e.g. productivity) processes in determining the different patterns observed in benthic and fish community structures in granite and limestone rocky habitats. Although appropriate experimentation and temporal replication are obviously needed to support the above arguments, this paper provides, for the first time, correlative evidence that the mineralogical composition of rocks may be involved in shaping marine communities (from epibenthos to fishes) associated with shallow subtidal rocky substrates.

Acknowledgements. The research was funded by MURSTCOFIN99 Project 'Ecological and biochemical interactions between aquatic biosystems and natural substrates'. Many thanks are due to R. Clarke (Plymouth Marine Laboratory, UK) for his helpful advice on multivariate analyses, to S. D. Connell (University of Adelaide, Australia) for his critical reading of the manuscript, and to 3 anonymous referees for their useful criticism.

\section{LITERATURE CITED}

Abbiati M, Bianchi CN, Castelli A (1987) Polychaete vertical zonation along a littoral cliff in the West Mediterranean. PSZN I: Mar Ecol 8:33-48

Abbiati M, Bianchi CN, Castelli A, Giangrande A, Lardicci C (1991) Distribution of polychaetes on hard substrates of the midlittoral-infralittoral transition zone, western Mediterranean. Ophelia (Suppl) 5:421-432

Airoldi L (2000) Responses of algae with different life histories to temporal and spatial variability of disturbance in subtidal reefs. Mar Ecol Prog Ser 195:81-92

Angel A, Ojeda FP (2001) Structure and trophic organization of subtidal fish assemblages on the northern Chilean coast: the effect of habitat complexity. Mar Ecol Prog Ser 217:81-91

Balduzzi A, Bianchi CN, Burlando B, Cattaneo-Vietti R and 5 others (1996) Zoobenthos di substrato duro delle isole di Capraia e del Giglio (Arcipelago Toscano). Atti Soc Toscana Sci Nat Mem Ser A 102(Suppl): 124-135

Barry JP, Dayton PK (1991) Physical heterogeneity and the organization of marine communities. In: Kolasa J, Pickett STA (eds) Ecological heterogeneity. Springer Verlag, New York, p 270-320

Bavestrello G, Bianchi CN, Calcinai B, Cattaneo-Vietti R, Cerrano C, Morri C, Puce S, Sarà M (2000) Bio-mineralogy as a structuring factor for marine epibenthic communities. Mar Ecol Prog Ser 193:241-249

Bell JD, Harmelin-Vivien ML (1983) Fish fauna of French Mediterranean Posidonia oceanica seagrass meadows. 2. Feeding habits. Téthys 11:1-14

Benedetti-Cecchi L, Cinelli F (1995) Habitat heterogeneity, sea urchin grazing and the distribution of algae in littoral rock pools on the west coast of Italy (western Mediterranean). Mar Ecol Prog Ser 126:203-212

Benedetti-Cecchi L, Bulleri F, Cinelli F (1998) Density dependent foraging of sea urchins in shallow subtidal reefs on the west coast of Italy (western Mediterranean). Mar Ecol Prog Ser 163:203-211

Benedetti-Cecchi L, Bulleri F, Cinelli F (2000) The interplay of physical and biological factors in maintaining mid-shore and low-shore assemblages on rocky coasts in the northwestern Mediterranean. Oecologia 123:406-417

Bianchi CN (1979) Ecologia dei Serpuloidea (Annelida, Polychaeta) del piano infralitorale presso Portofino (Genova). Boll Mus Ist Biol Univ Genova 47:101-115

Bianchi CN (1997) Climate change and biological response in the marine benthos. Proc Ital Assoc Oceanol Limnol 12: $3-20$

Boudouresque CF (1984) Groupes écologiques d'algues marines et phytocénoses benthiques en Méditerranée NordOccidentale: une revue. G Bot Ital 118(Suppl 2):111-114

Boudouresque CF, Verlaque M (2001) Ecology of Paracentrotus lividus. In: Lawrence JM (ed) Edible sea urchins: biology and ecology. Elsevier, Amsterdam, p 177-216

Bourget E, De Guise J, Daigle G (1994) Scales of substratum heterogeneity, structural complexity, and the early establishment of a marine epibenthic community. J Exp Mar Biol Ecol 181:31-51

Bruno JF, Stachowicz JJ, Bertness MD (2003) Inclusion of facilitation into ecological theory. Trends Ecol Evol 18: $119-125$

Bulleri F, Benedetti-Cecchi L, Cinelli F (1999) Grazing by the sea urchins Arbacia lixula L. and Paracentrotus lividus Lam. in the Northwest Mediterranean. J Exp Mar Biol Ecol 241:81-95

Bussotti S, Guidetti P, Belmonte G (2003) Distribution patterns 
of the cardinal fish, Apogon imberbis, in shallow marine caves in southern Apulia (SE Italy). Ital J Zool 70:153-157

Caffey HM (1982) No effect of naturally-occurring rock types on settlement or survival in the intertidal barnacle, Tesseropora rosea (Krauss). J Exp Mar Biol Ecol 63: $119-132$

Cattaneo-Vietti R, Albertelli G, Bavestrello G, Bianchi CN and 5 others (2002) Can rock composition affect sublittoral epibenthic communities? PSZN I: Mar Ecol 23:65-77

Cerrano C, Arillo A, Bavestrello G, Benatti U and 7 others (1998) Organism-quartz interactions in structuring benthic communities: towards a marine bio-mineralogy? Ecol Lett 2:1-3

Chapman MG (2003) The use of sandstone blocks to test hypotheses about colonization of intertidal boulders. J Mar Biol Assoc UK 83:415-423

Chemello R, Milazzo M (2002) Effect of algal architecture on associated fauna: some evidence from phytal molluscs. Mar Biol 140:981-990

Clarke KR (1993) Non-parametric multivariate analyses of changes in community structure. Austr J Ecol 18:117-143

Clarke KR, Warwick RM (1994) Change in marine communities: an approach to statistical analysis and interpretation. Natural Environment Research Council

Connell SD, Glasby TM (1999) Do urban structures influence local abundance and diversity of subtidal epibiota? A case study from Sidney Harbour, Australia. Mar Environ Res 47:373-387

Dayton PK (1984) Processes structuring some marine communities: are they general? In: Strong D, Simberloff DS, Thistle AB (eds) Ecological communities: conceptual issues and the evidence. Princeton University Press, Princeton, NJ, p 181-197

Den Hartog C (1972) Substratum. In: Kinne O (ed) Marine ecology, Vol 1, Part 3. Wiley-Interscience, Chichester, p 1277-1289

Duffy JE (2002) Biodiversity and ecosystem function: the consumer connection. Oikos 99:201-219

Duffy JE, Hay ME (2001) The ecology and evolution of marine consumer-prey interactions. In: Bertness MD, Gaines SD, Hay ME (eds) Marine community ecology. Sinauer Associates, Sunderland, MA, p 131-157

Faimali M, Garaventa F, Terlizzi A, Chiantore M, CattaneoVietti R (2004) The interplay of substrate nature and biofilm formation in regulating Balanus amphitrite Darwin, 1854 larval settlement. J Exp Mar Biol Ecol 306:37-50

Fraschetti S, Bianchi CN, Terlizzi A, Fanelli G, Morri C, Boero F (2001) Spatial variability and human disturbance in shallow subtidal hard substrate assemblages: a regional approach. Mar Ecol Prog Ser 212:1-12

Gaino E, Cianficconi F, Rebora M, Todini B (2002) Casebuilding of some Trichoptera larvae in experimental conditions: selectivity for calcareous and siliceous grains. Ital J Zool 69:141-145

Garcìa-Charton JA, Pérez-Ruzafa A (1998) Correlation between habitat structure and a rocky reef fish assemblage in SW Mediterranean. PSZN I: Mar Ecol 19:111-128

Garcìa-Charton JA, Pérez-Ruzafa A (2001) Spatial patterns and the habitat structure of a Mediterranean rocky reef fish local assemblage. Mar Biol 138:917-934

Garcìa-Rubies A, Macpherson E (1995) Substrate use and temporal pattern of recruitment in juvenile fishes of the Mediterranean littoral. Mar Biol 124:35-42

Glasby TM (2000) Surface composition and orientation interact to affect subtidal epibiota. J Exp Mar Biol Ecol 248: $177-190$

Guidetti P, Cattaneo-Vietti R (2002) Can mineralogical fea- tures influence distribution patterns of fish? A case study in shallow Mediterranean rocky reefs. J Mar Biol Assoc UK 82:1043-1044

Guidetti P, Bianchi CN, La Mesa G, Modena M, Morri C, Sara G, Vacchi M (2002) Abundance and size structure of Thalassoma pavo (Pisces: Labridae) in the western Mediterranean: variability at different spatial scales. J Mar Biol Assoc UK 82:495-500

Guidetti P, Fraschetti S, Terlizzi A, Boero F (2003) Distribution patterns of sea urchins and barrens in shallow Mediterranean rocky reefs impacted by the illegal fishery of the rock-boring mollusc Lithophaga lithophaga. Mar Biol 143: $1135-1142$

Guidetti P, Fraschetti S, Terlizzi A, Boero F (in press) Effects of desertification caused by Lithophaga lithophaga (Mollusca) fishery on littoral fish assemblages along rocky coasts of Southeastern Italy. Conserv Biol

Hairston NG, Smith FE, Slobodkin LB (1960) Community structure, population control, and competition. Am Nat 94: 421-425

Harmelin-Vivien ML, Harmelin JG, Chauvet C, Duval C and 7 others (1985) Evaluation des peuplements et populations de poissons: méthodes et problèmes. Rev Ecol Terre Vie 40:467-539

Horne JK, Schneider DC (1995) Spatial variance in ecology. Oikos 7:18-26

Hunter MD, Price PW (1992) Playing chutes and ladders: heterogeneity and the relative roles of bottom-up and topdown forces in natural communities. Ecology 73:724-732

Letourneur Y, Ruitton S, Sartoretto S (2003) Environmental and benthic factors structuring the spatial distribution of a summer infralittoral fish assemblage in the north-western Mediterranean Sea. J Mar Biol Assoc UK 83:193-204

Levin PS (1993) Habitat structure, conspecific presence and spatial variation in the recruitment of a temperate fish. Oecologia 94:176-185

Luckhurst BE, Luckhurst K (1978) Analysis of the influence of substrate variables on coral reef fish communities. Mar Biol 49:317-323

Manini E, Luna GM (2003) Influence of the mineralogical composition on microbial activities in marine sediments: an experimental approach. Chem Ecol 19:399-410

Maradonna F, Bavestrello G, Cardinali M, Olivotto I, Cerrano C, Giovine M, Carnevali O (2003) Role of substrate on larval development of the freshwater teleost Pelvicachromis pulcher. Mol Reprod Dev 66:256-263

Menge BA (2000) Top-down and bottom-up community regulation in marine rocky intertidal habitats. J Exp Mar Biol Ecol 250:257-289

Menge BA, Southerland JP (1987) Community regulation: variation in disturbance, competition and predation in relation to environmental stress and recruitment. Am Nat 130:730-757

Navone A, Bianchi CN, Orrù P, Ulzega A (1992) Saggio di cartografia geomorfologica e bionomica nel parco marino di Tavolara-Capo Coda Cavallo. Oebalia 17(Suppl):469-478

Paine RT (1980) Food webs, linkage, interaction strength, and community infrastructure. J Anim Ecol 49:667-685

Paine RT, Levin SA (1981) Intertidal landscapes: disturbance and the dynamics of pattern. Ecol Monogr 51:145-178

Pinnegar JK, Polunin NVC, Francour P, Badalamenti F and 7 others (2000) Trophic cascades in benthic marine ecosystems: lessons for fisheries and protected-area management. Environ Conserv 27:179-200

Raimondi PT (1988) Rock type affects settlement, recruitment, and zonation of the barnacle Chthamalus anisopoma (Pilsbry). J Exp Mar Biol Ecol 123:253-267 
Roberts CM, Ormond RF (1987) Habitat complexity and coral reef fish diversity and abundance on Red Sea fringing reefs. Mar Ecol Prog Ser 41:1-8

Ruitton S, Francour P, Boudouresque CF (2000) Relationships between algae, benthic herbivorous invertebrates and fishes in rocky sublittoral communities of a temperate sea (Mediterranean). Estuar Coast Shelf Sci 50:217-230

Sala E, Zabala M (1996) Fish predation and the structure of the sea urchin Paracentrotus lividus populations in the NW Mediterranean. Mar Ecol Prog Ser 140:71-81

Sala E, Boudouresque CF, Harmelin-Vivien ML (1998a) Fishing, trophic cascades, and the structure of algal assemblages: evaluation of an old but untested paradigm. Oikos 82:425-439

Sala E, Ribes M, Hereu B, Zabala M, Alvà V, Coma R, Garrabou J (1998b) Temporal variability in abundance of the sea urchins Paracentrotus lividus and Arbacia lixula in the northwestern Mediterranean: comparison between a marine reserve and an unprotected area. Mar Ecol Prog Ser 168:135-145

Sardá R (1991) Polychaete communities related to plant covering in the mediolittoral and infralittoral zones of the Balearic islands (Western Mediterranean). PSZN I: Mar Ecol 12:342-360

Schiaparelli S, Guidetti P, Cattaneo-Vietti R (2003) Can mineralogical features affect the distribution patterns of sessile gastropods? The Vermetidae case in the Mediterranean Sea. J Mar Biol Assoc UK 83:1267-1268

Simboura N, Zenetos A, Thessalou-Legaki M, Pancucci MA, Nicolaidou A (1995) Benthic communities of the infralit-

Editorial responsibility: Roger Hughes (Contributing Editor), Bangor, UK toral in the N. Sporades (Aegean Sea): a variety of biotopes encountered and analysed. PSZN I: Mar Ecol 16: 283-306

Smith F, Witman JD (1999) Species diversity in subtidal landscapes: maintenance by physical processes and larval recruitment. Ecology 80:51-69

Sousa WP (1984) Intertidal mosaics: patch size, propagule availability and spatial variable patterns of succession. Ecology 65:1918-1935

Sousa WP (2001) Natural disturbance and the dynamics of marine benthic communities. In: Bertness MD, Gaines SD, Hay ME (eds) Marine community ecology. Sinauer Associates, Sunderland, MA, p 85-130

Tortonese E (1975) Osteichthyes: pesci ossei (parte seconda). Fauna d'Italia, Vol 11. Calderini, Bologna

Turner SJ, Thrush SF, Hewitt JE, Cummings VJ, Funnell G (1999) Fishing impacts and the degradation or loss of habitat structure. Fish Manag Ecol 6:401-420

Underwood AJ (1997) Experiments in ecology: their logic design and interpretation using analysis of variance. Cambridge University Press, Cambridge

Wellenreuther M, Connell SD (2002) Response of predators to prey abundance: separating the effects of prey density and patch size. J Exp Mar Biol Ecol 273:61-71

White TRC (1978) The importance of relative shortage of food in animal ecology. Oecologia 33:233-242

Witman JD, Dayton PK (2001) Rocky subtidal communities In: Bertness MD, Gaines SD, Hay ME (Eds) Marine community ecology. Sinauer Associates, Sunderland, MA, p 339-366

Submitted: October 20, 2003; Accepted: March 22, 2004

Proofs received from author(s): June 11, 2004 